\title{
Assessment of the Ecological Status and Threats of Welala and Shesher Wetlands, Lake Tana Sub-Basin (Ethiopia)
}

\author{
Negash Atnafu ${ }^{1}$, Eshete Dejen ${ }^{2}$, Jacobus Vijverberg ${ }^{3}$ \\ ${ }^{1}$ Amhara Tourism and Culture Bureau, Bahir Dar, Ethiopia \\ ${ }^{2}$ Food and Agricultural Organization, Subregional Office for Eastern Africa, Addis Ababa, Ethiopia \\ ${ }^{3}$ Department of Aquatic Ecology, Netherlands Institute of Ecology (NIOO-KNAW), \\ Wageningen, The Netherlands \\ E-mail:negashatinafu@yahoo.com,Eshete.Dejen@fao.org,dejeneshete@yahoo.com,j.vijverberg@nioo.knaw.nl \\ Received April 27, 2011; revised May 29, 2011; accepted July 2, 2011
}

\begin{abstract}
The ecological status of the Welala and Shesher Wetlands, on the eastern side of Lake Tana, were studied during pre-rainy, main-rainy, post-rainy and dry seasons from May 2009 to January 2010. Species composition, diversity and abundance of macrophytes, benthic macro-invertebrates and birds were assessed and physico-chemical parameters were measured. Phosphate and silicate concentrations, conductivity, TDS and turbidity varied significantly $(\mathrm{p}<0.05)$ between dry and wet seasons in both wetlands. Physico-chemical parameters did not differ $(\mathrm{p}>0.05)$ between the two wetlands. The values for dissolved oxygen and $\mathrm{pH}$ ranged between $4.8-7.8 \mathrm{mg} / 1$ and 6.7 - 7.6, respectively. The values for nitrate and phosphate ranged between 0.2 $3.1 \mathrm{mg} / 1$ and $0.2-3.3 \mathrm{mg} / 1$, respectively. A total of 274 benthic macro-invertebrate individuals belonging to 5 families were collected, 32, 699 individual birds belonging to 62 species were enumerated and 13 species of macrophytes were identified. The two wetlands are shrinking at an alarming rate, mainly because of unsustainable farming practices and a huge irrigation project on Ribb River which is at presently under construction. Farming practices include draining and pumping of water for irrigation and expansion of farmland at the cost of the wetlands. The construction of a dam in Ribb River prevents overflow from Ribb River into the wetlands and disrupts the connection with Lake Tana which is vital for the survival of these two wetlands. We conclude that the Welala and Shesher Wetlands are valuable wetlands which need urgently protection.
\end{abstract}

Keywords: Fogera, Macrophytes, Macro-Invertebrates, Birds, Abundance, Species Composition, Species Diversity, Socio-Economics

\section{Introduction}

The different geological formations and climatic conditions have endowed Ethiopia with vast water resources and wetland ecosystems including 12 river basins, 8 major lakes and many swamps, floodplains, and man-made reservoirs with a total annual surface runoff of about 110 billion cubic meters [1]. It is estimated that Ethiopian wetlands cover an area of $13,699 \mathrm{~km}^{2}$ or $1.14 \%$ of the country's land surface [2].

Wetlands have many socio-economic and ecological

"Publication costs were covered by a grant from Prof. Dr. Jan Osse (Wageningen University). benefits. The values and services gained from wetlands can be categorized into functions, products and attributes [3].

Despite the benefits gained from wetlands they are under threat from the conversion of wetlands for intensive irrigation agriculture, the expansion of human settlements, industrial pollution, agricultural pollution by pesticides, use of fertilizers, water diversion for drainage and the construction of dams.

Fogera floodplains including Welala and Shesher Wetlands are one of the 73 hot spots in Ethiopia which are identified as important bird areas. They provide shelter to the endemic, globally endangered, vulnerable and near threatened species of birds [4,5]. The local commu- 
nity gets benefits from Welala and Shesher Wetlands in the form of fishing, grazing for cattle and small scale irrigation. These valuable wetlands are under threat from overgrazing, drainage, water diversions for small irrigations and conversion into farmlands. Although several studies were conducted on Fogera floodplains, an in depth study with particular reference to Welala and Shesher Wetlands was lacking.

This study on physico-chemical water parameters, socio-economic aspects and species composition, diversity and abundance of macrophytes, benthic macro-invertebrates and birds is fundamental for the understanding of the ecological status of these wetlands. The study will serve as a baseline to what extent the wetlands are affected by the surrounding land use and could be used to monitor changes due to planned massive irrigation and hydropower generation projects around Lake Tana [6]. It will also serve as information for planners and decision makers to consider in future development plans.

\section{Materials and Methods}

\subsection{Study Area}

Lake Tana is Ethiopia's largest lake $\left(3150 \mathrm{~km}^{2}\right)$ and is situated in the northwestern highlands at an altitude of approximately $1800 \mathrm{~m}$. It is shallow (maximum depth 14 $\mathrm{m}$, mean $8 \mathrm{~m}$ ). Several large and small rivers including Gumara, Ribb, Megech, Gilgel Abay, Arno Garno and Dirma (maximum length $60 \mathrm{~km}$ ) enter the lake, and the Blue Nile is its only outflow.

Fogera and Dembia floodplains are the largest wetlands of the country and are connected with Lake Tana. The study was conducted in Fogera Woreda of the Amhara National Regional State (ANRS). Fogera Woreda is one of the ten Woreda's bordering Lake Tana and is found in South Gondar Administrative Zone. It is situated at 11058'00" N latitude and 37041'00" E longitudes. Woreta, capital of the Fogera Woreda is found $620 \mathrm{~km}$ from Addis Ababa and $55 \mathrm{~km}$ from the regional capital, Bahir Dar [7] (Figure 1).

\subsection{Climate}

The mean annual rainfall of the area is $1216.3 \mathrm{~mm}$ and ranges from 1103 to $1336 \mathrm{~mm}$. The climate around $\mathrm{L}$. Tana is characterized by four seasons: 1) a main-rainy season with heavy rains during June-August, 2) a dry season during December-February, 3) a pre-rainy season during March-May and 4) a post-rainy season during September-November. After the main-rainy season there are the two cropping seasons. Maize, finger millet, sorghum, teff, rice, wheat and noug are the main crops grow- ing in the study area [7].

\subsection{Sampling and Data Collecting}

Two sites at the center and periphery of both ponds were chosen for sampling physico-chemical parameters. For the measurements of chemical parameters: phosphate, nitrate and silicate, the procedures outlined in a manual on standard methods for examination of wastewater was employed [8].

Physical parameters measured were conductivity, water temperature, dissolved oxygen, transparency, $\mathrm{pH}$ and TDS. Samples were taken at one site in the middle of each pond. Water temperature, $\mathrm{pH}$ and dissolved oxygen were measured with a combined portable pH/oxygen/ temperature meter (YSI model 58). Conductivity was measured using Hanna conductivity meter. Measurements on transparency were made using the standard Secchi disk (25 cm in diameter).

Benthic macro-invertebrates were sampled twice, once in September and a second time in December. Two sampling stations were chosen for each pond, one at the periphery and one in the middle of each pond. Samples were preserved in $95 \%$ ethanol following standard operating procedures for benthic macro-invertebrate sampling and processing [9]. Identification and enumeration of benthic macro-invertebrates was made at Bahir Dar Fishery and Other Aquatic Life Research Center's laboratory. Identification of macro-invertebrates was made using standard keys [10-12].

Vegetation data were collected along two systematically placed north-south transect lines in both ponds [13]. One transect passed approximately in the middle of vegetated zone and the other passed along open water. At every 500 meters interval the vegetation was studied of in total 10 quadrants with an area of $0.5 \mathrm{~m} \mathrm{x} 0.5 \mathrm{~m}$ each. The minimum area and number of the quadrants to be studied were determined according to the procedures given by [14]. Field guide books were used for identification of macrophytes [15-17].

Observations on birds were carried out over the whole study area. A total of 8 counting stations were laid systematically along north-south extension of both sites at 400 meters interval. At each station birds within the radius of $200 \mathrm{~m}$ were identified and counted. Data was collected from 6:30 a.m. to $10 \mathrm{a} . \mathrm{m}$. in the morning and from 4:30 p.m. to 6:00 p.m. in the afternoon following standard methods [18]. Counting of birds was carried out according to the procedures recommended by the British Royal Geographical Society [19]. For identification field guide books were used [20,21].

Socio-economic data was collected in two villages, Nabega and Shaga. A total of 40 questioners, 20 for each 


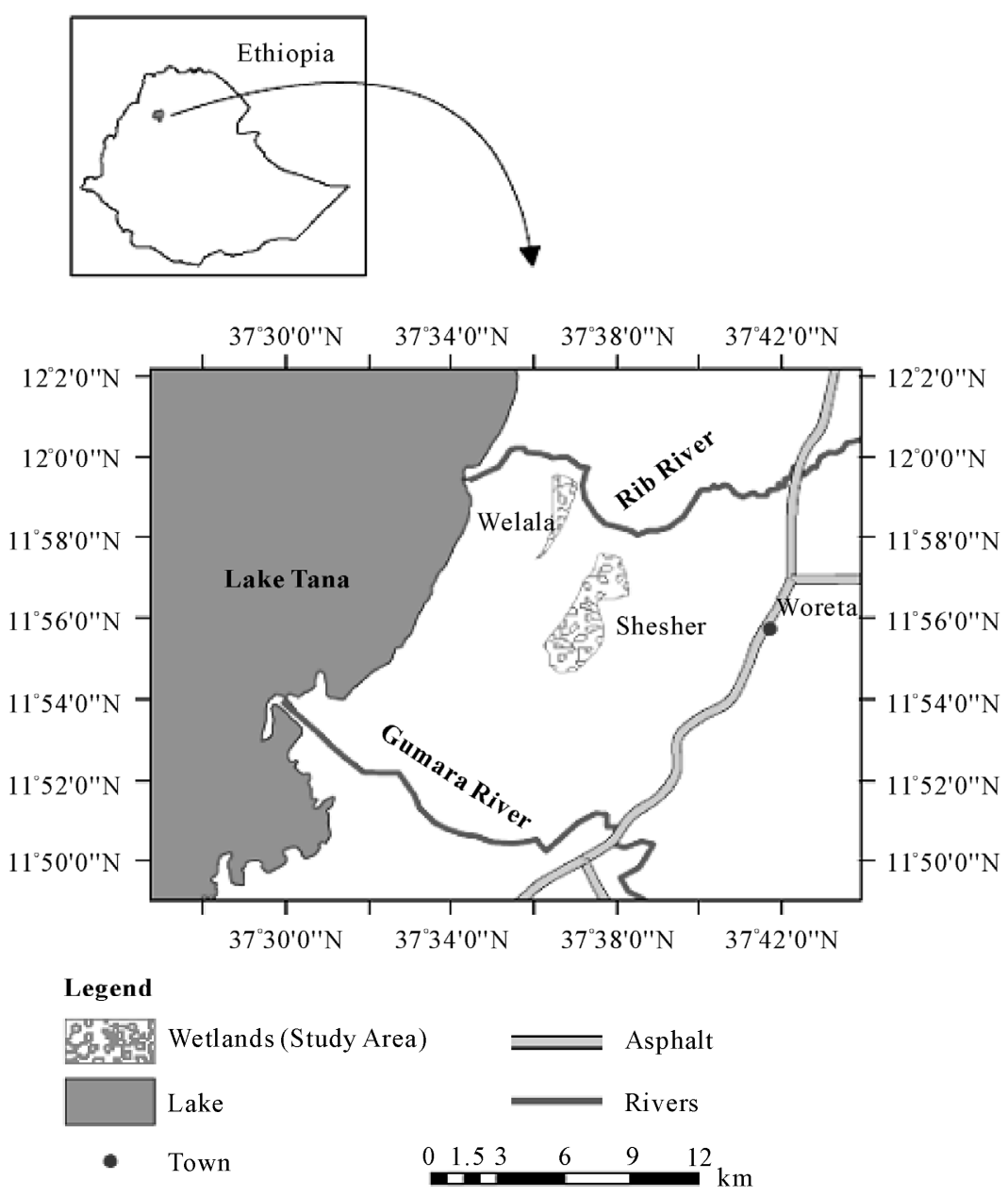

Figure 1. Map of the study area.

village were administered.

\subsection{Data Analysis}

The data collected was entered into SPSS software program. To analyze physico-chemical parameters, benthic macro-invertebrates and socio-economic data descriptive statistics was employed. To evaluate the significance of spatial and temporal variations of physico-chemical parameters the Kruskal-Wallis test was performed. Spearman bivariate correlation analysis was done to relate benthic macro-invertebrate densities to physico-chemical parameters. To describe the diversity of bird and macrophyte species the Shannon-Wiener Diversity Index ( $\left.\mathrm{H}^{\prime}\right)$ was calculated.

\section{Result and Discussion}

\subsection{Physco-Chemical Parameter}

The measurements, means and standard errors (SE) of the analyzed parameters are presented in Table 1. The lowest temperatures were recorded in Shesher during the dry season and the highest at the same site during the post-rainy season. Conductivity was in the range of 0.18 250 and $0.08-197 \mu \mathrm{S} / \mathrm{cm}$ in Shesher and Welala, respectively, which is within the range for fresh water (10 $1000 \mu \mathrm{S} / \mathrm{cm}$ ) [22]. Turbidity was very high during rainy season (Secchi disc depth: $3 \mathrm{~cm}$ ). In both sites $\mathrm{pH}$ values varied within narrow limits (range $6.7-7.8$ ); this meets the quality standards for surface water of Ethiopia (range: 6.0 - 9.0) [23]. In both wetlands dissolved oxygen levels ranged between 4.8 and $7.8 \mathrm{mg} / 1$, which are generally considered favorable for most aquatic organisms [24]. Nitrate concentrations were low, well below the limit of $5 \mathrm{mg} / \mathrm{l}$ above which they would become toxic for aquatic organisms [22]. Silicate concentrations declined from 8.5 $19.5 \mathrm{mg} / \mathrm{l}$ in rainy season to $0.6 \mathrm{mg} / \mathrm{l}$ in dry season.

There were no significant differences in physicochemical parameters between Shesher and Welala (Kruskal-Wallis test, $\mathrm{p}>0.05$ ). Thus nitrate, phosphate, silicate, temperature, $\mathrm{pH}$, dissolved oxygen, conductivity, 
Table 1. Seasonal variation of physco-chemical parameter in Welala and Shesher Wetlands. Rainy season includes main-rainy and pre-rainy season. $\mathrm{SE}=$ Standard Error.

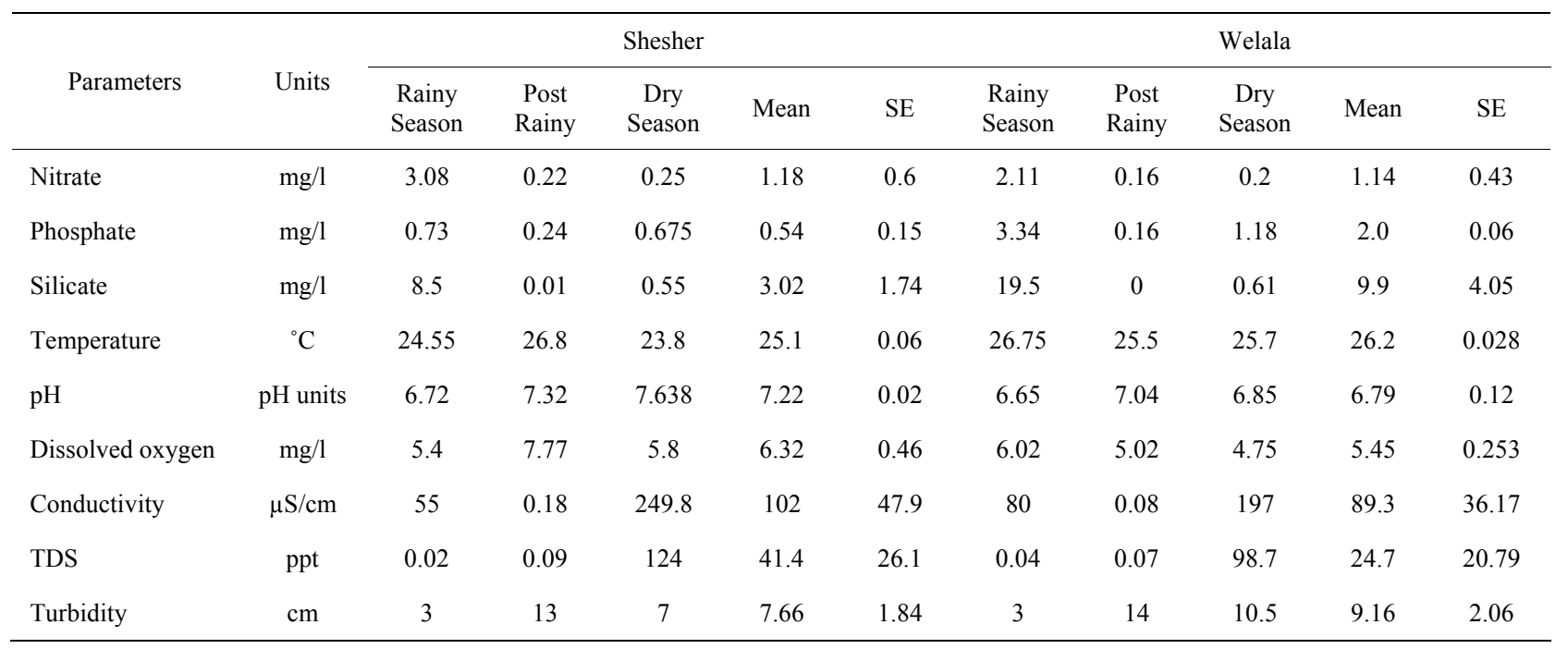

TDS and turbidity were the same in the two places. This may be partly due to the similarity of habitat and partly due to the mixing of surface water during the rainy season through the canal which connects Shesher with Welala. Furthermore, they share the same catchment. However, there were significance differences in the phosphate and silicate concentrations and in turbidity between the dry and the wet season $(p<0.05)$. This may be due to inputs from the catchment during the rainy season and subsequent settlement during the dry season. Furthermore, uptake of silicate and phosphate by phytoplankton might also have led to the reduction of these two nutrients in the dry season.

\subsection{Benthic Macro-Invertebrates}

A total of 274 benthic macro-invertebrate individuals belonging to 5 families were collected during the survey. Their abundance and spatial distribution are shown in Table 2.

Bivalva were not found in Shesher Wetland and only in two sampling sites in Welala. The number of individuals per sampling site ranged from 0 - 61. Chironomidae were the most abundant (70\%) followed by Oligochaeta $(25 \%)$, whereas Bivalva was the least represented family (Figure 2).

The results of the Spearman Correlation analyses are shown in Table 3. Oligochaeta showed strong negative correlations with phosphate $(\mathrm{r}=-0.718, \mathrm{p}<0.05)$, silicate $(\mathrm{r}=-0.878, \mathrm{p}<0.05)$, conductivity $(\mathrm{r}=-0.892, \mathrm{p}<$ 0.05 and TDS $(\mathrm{r}=-0.893, \mathrm{p}<0.05)$. It also showed a very strong positive correlation with oxygen $(r=0.918, p$ $<0.05$ ). A strong positive correlation was also observed between Hirudinea and turbidity $(\mathrm{r}=0.792, \mathrm{p}<0.05)$.
This may be partly due to high tolerance of Hirudinea to high turbidity conditions and partly to release of competition for food as the sensitive groups were removed. Chironomidae showed strong positive correlations with phosphate, silicate, conductivity and TDS. There was a strong negative correlation between Coleoptera and turbidity. Sediment load from run off in the surrounding catchments which induce a rise in turbidity may have inhibited Coleoptera larvae. Excessive sediment load is often a major contributor to the decline of a stream's benthic community [24]. Bivalva showed a strong negative correlation with both temperature and turbidity. All families encountered except Coleoptera larvae were pollution tolerant [9].

\subsection{Macrophyte Abundance and Diversity}

Information about relative abundance and dominance of macrophyte taxa are summarized in Table 4. Abundance parameters were calculated over all quadrants in the two wetlands. Relative abundance (RA) of a species is the average relative density (\%) of that species relative to all species present. The relative frequency $(\mathrm{RF})$ of a species is the average absolute frequency of that species per quadrant divided by the sum of the absolute frequencies of all species present. Relative density (RD) of a species is the average absolute density per quadrant of that species divided by the total average density of all species present. Relative dominance (RDO) of a species is the average space covered (\%) by that species relative to the coverage of all species present.

A total of 13 taxa were identified from the 20 quadrants of Welala and Shesher Wetlands (Table 4). Ludwigia spp. were the most abundant (23\%) followed by Lemna 
Table 2. Abundance of macro-invertabrates in Welala and Shesher Wetlands at two sampling sites; S1 = Sampling site one, S2 = Sampling site two. Numbers per sampling site and average abundance of taxa in numbers per $\mathbf{~}^{2}$.

\begin{tabular}{|c|c|c|c|c|c|c|c|c|c|}
\hline \multirow{3}{*}{ Taxa/family } & \multicolumn{4}{|c|}{ Welala } & \multicolumn{4}{|c|}{ Shesher } & \multirow{3}{*}{ Abundance $/ \mathrm{m}^{2}$} \\
\hline & \multicolumn{2}{|c|}{ September } & \multicolumn{2}{|c|}{ December } & \multicolumn{2}{|c|}{ September } & \multicolumn{2}{|c|}{ December } & \\
\hline & S1 & S2 & S1 & S2 & S1 & S2 & S1 & S2 & \\
\hline Oligochaeta & 22 & 20 & 4 & 3 & 5 & 7 & 3 & 4 & 5666.67 \\
\hline Hirudinea & 1 & 2 & 0 & 0 & 2 & 1 & 0 & 0 & 500 \\
\hline Chironomidae & 4 & 6 & 30 & 25 & 5 & 7 & 61 & 55 & 16083.33 \\
\hline Coleoptera & 0 & 0 & 2 & 3 & 0 & 0 & 0 & 0 & 416.67 \\
\hline Bivalva & 0 & 0 & 1 & 1 & 0 & 0 & 0 & 0 & 166.67 \\
\hline
\end{tabular}

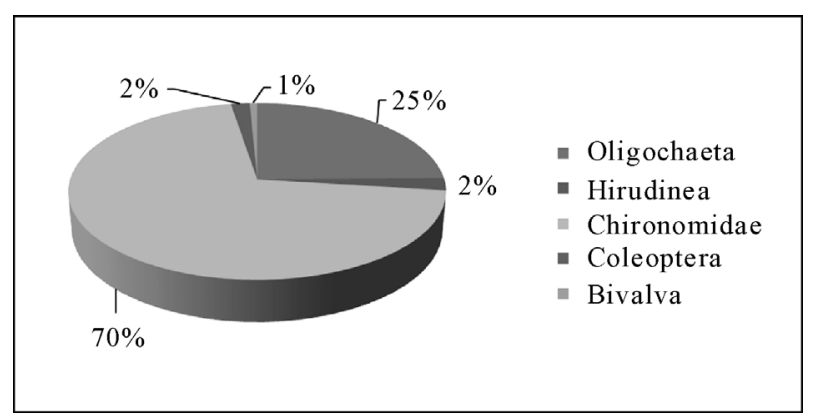

Figure 2. Abundance of benthic macro-invertebrates in Shesher and Welala Wetlands.

Table 3. Correlation between physico-chemical parameters and benthic macro-invertebrate densities.

\begin{tabular}{cccc}
\hline Taxa/family & Physicochemical parameters & $\mathrm{R}$ & P-value \\
\hline \multirow{2}{*}{ Oligochaeta } & Dissolved Oxygen & 0.918 & 0.001 \\
& Phosphate & -0.718 & 0.045 \\
& Silicate & -0.878 & 0.004 \\
& Conductivity & -0.892 & 0.003 \\
Hirudinea & TDS & -0.893 & 0.003 \\
\hline \multirow{2}{*}{ Chironomidae } & Turbidity & 0.792 & 0.019 \\
\hline Phosphate & 0.856 & 0.007 \\
& Silicate & 0.882 & 0.004 \\
Coleoptera & TDS & 0.768 & 0.026 \\
& phH & 0.771 & 0.025 \\
\hline Bivalva & Turbidity & -0.855 & 0.007 \\
\hline & Temperature & -0.789 & 0.02 \\
& Turbidity & -0.878 & 0.004 \\
\hline
\end{tabular}

Table 4. Relative abundance (RA, \%), relative frequency (RF), relative density (RD) and relative dominance (RDO) of macrophyte taxa.

\begin{tabular}{lcccc}
\hline \multicolumn{1}{c}{ Species } & $\mathrm{RA}$ & $\mathrm{RF}$ & $\mathrm{RD}$ & $\mathrm{RDO}$ \\
\hline Scirpus spp. & 3.5 & 0.15 & 5 & 0.05 \\
Sparganium spp. & 7 & 0.15 & 5 & 0.05 \\
Phragmites australis & 4.5 & 0.15 & 7 & 0.07 \\
Cyperaceae family & 7.5 & 0.25 & 3 & 0.03 \\
Ludwigia spp. & 23.22 & 0.75 & 19 & 0.19 \\
Nuphar lutea & 2.4 & 0.25 & 9 & 0.09 \\
Nymphaea spp. & 1 & 0.2 & 6 & 0.06 \\
Lemna spp. & 16.8 & 0.65 & 20 & 0.2 \\
Chara spp. & 16 & 0.55 & 10 & 0.1 \\
Papaveraceae & 8.88 & 0.45 & 4 & 0.04 \\
Sacciolepis africana & 3.5 & 0.25 & 2 & 0.02 \\
Argemone mexicana & 3.2 & 0.25 & 2 & 0.02 \\
Brassicaceae & 2.5 & 0.25 & 2 & 0.02 \\
\hline
\end{tabular}

spp. (17\%) and Chara spp. (16\%). Nymphaea spp. were the least represented (1\%) followed by Nuphar lutea (2\%). Two species, Phragmites australis and Nuphar lutea were absent in Shesher. The results indicate that Ludwigia spp. were more abundant, more frequent and covered most of the area. Ludwigia spp. are good quality food for waterfowl [25].

Diversity of macrophytes in Welala and Shesher Wetlands are given in Table 5. The Shannon diversity index was 2.28 for Welala and 1.92 for Shesher. The Shannon diversity index normally varies between 1.5 and 3.5 and rarely exceeds 4.5 [26]. The evenness index was 0.89 for Welala and 0.83 for Shesher. The site which has the larger number of species (Welala, 13 species) has a greater diversity index than the site with lower number of 
Table 5. Diversity of macrophytes in Welala and Shesher Wetlands. $\mathbf{H}^{\prime}=$ Shannon-Wiener Diversity Index, $\mathbf{H}_{\max }=\mathbf{l n}$ (total numbers of species), $\mathbf{H} / \mathbf{H}_{\max }=$ Evenness.

\begin{tabular}{ccccc}
\hline Habitat & Number of Species & $\mathrm{H}^{\prime}$ & $\mathrm{H}_{\max }$ & $\mathrm{H}^{\prime} \mathrm{H}_{\max }$ \\
\hline Welala & 13 & 2.28 & 2.57 & 0.89 \\
Shesher & 10 & 1.92 & 2.30 & 0.83 \\
\hline
\end{tabular}

species (Shesher, 10 species). The Sorensen's similarity coefficient calculated between the two sites was 0.8 . This coefficient varies between 0 (complete dissimilarity) to 1 (total similarity) [17]. We conclude that both sites have very similar macrophyte vegetation and show relative low macrophyte diversity. The high similarity may be due to the resemblance of the two habitats.

\subsection{Abundance and Diversity of Birds}

From the two wetlands a total of 62 species consisting of 32, 699 individuals were recorded. In Welala the highest number was recorded in pre-rainy season $(12,381$ individuals) as compared to dry season (4,663 individuals). In Shesher the highest number was recorded in dry season $(11,725$ individuals) compared to pre-rainy season (3,930 individuals). In rainy season, birds were not observed (Figure 3). We found that during the beginning of the dry season Shesher Wetland was larger in area than Welala, which explains the larger population of birds during this season in Shesher. As the dry season advanced Shesher Wetland shrunk more rapidly than Welala and it dried up towards pre-rainy season before this occurred in Welala. It seems that when Shesher shrank and dried up the birds shifted to Welala. Therefore, in pre-rainy season we observed a large bird population in Welala.

In rainy season the two sites were flooded and we observed that birds abandoned the two wetlands, they were seen scattered over a large area around Woreta town. This agrees with observations reported in the literature that during the wet season waterfowl species often migrate to dryer area to escape from extreme flooding [4, 27]. In both wetlands Egyptian Goose (Alopochen aegyptiacus) was the most abundant followed by Curlew Sandpiper (Calidris ferruginea), Common Crane (Grus grus), Black Crowned Crane (Balearica pavonina), Spur-winged Goose (Plectropterus gambensis) and Ruff (Philomachus pugnax). Eurasian Marsh Harrier (Circus aeruginosus), White Headed Vulture (Aegypius occipitalis), Yellow-billed Stork (Mycteria ibis) and Little Grebe (Tachybaptus ruficollis) were the least abundant. Greater Flamingo (Phoenicopterus ruber) and Lesser Flamingo (Phoeniconaias minor) were observed in pre-rainy season in Welala only, presumably because of the merit of favorable food.

Three different diversity indices were calculated for the two sites (Table 6). The Shannon Diversity Index was 2.9 for both sites. This index normally varies between 1.5 and 3.5 and rarely exceeds 4.5 [26]. It is concluded that the two sites have a high diversity of bird species. Simpson's Similarity Index between the two sites was 0.97 . This index ranges from 0 (complete dissimilarity) to 1 (total similarity) [17]. It shows that the species composition in the two sites is very similar. This similarity may be due to the resemblance of the two habitats. The results show that the two wetlands are rich in bird diversity and abundance. We conclude that these wetlands are important habitats that need to be well protected to support and sustain the existing bird populations.

From the birds encountered the highest proportion were residents (62\%), followed by Northern Migrants (35\%) and Intra African Migrants (3\%). Inter African Migrants $(<1 \%)$ and endemic birds $(<1 \%)$ were re- presented by one species only, the Glossy Ibis (Plegadis falcinellus) and the Watteled Ibis (Bostrychia carunculata), respectively.

\subsection{Values and Threats}

Socio-economic information was collected in two villages, Nabega and Shaga using questioners. As to the

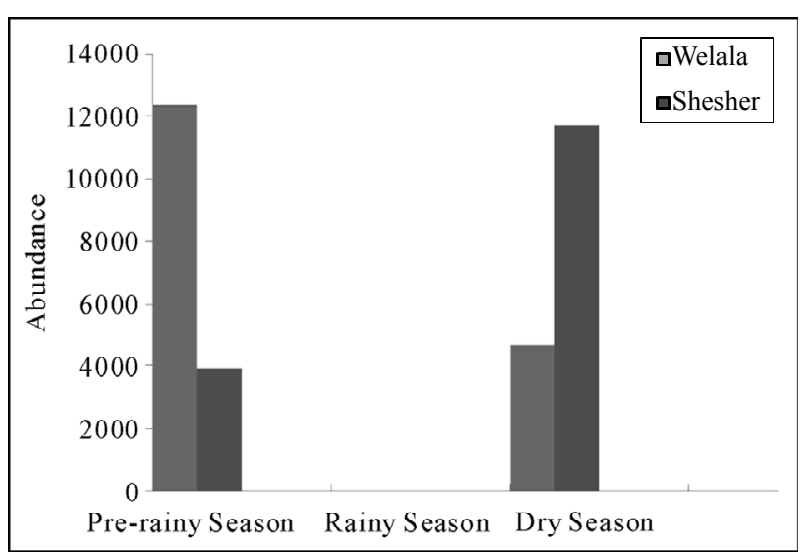

Figure 3. Seasonal abundance of birds in Welala and Shesher Wetlands. Abundance of birds in numbers observed per week.

Table 6. Diversity of birds in Welala and Shesher Wetlands. $H^{\prime}$ = Shannon-Wiener Diversity Index, $\mathbf{H}_{\max }=\ln$ (total numbers of species), E (Pielou's Evenness Index) $=\mathbf{H}^{\prime} / \mathbf{H}_{\max }$.

\begin{tabular}{ccccc}
\hline Habitat & Number of Species & $\mathrm{H}^{\prime}$ & $\mathrm{H}_{\max }$ & $\mathrm{E}$ \\
\hline Welala & 62 & 2.910 & 4.127134 & 0.70509 \\
Shesher & 60 & 2.885 & 4.094345 & 0.70468 \\
\hline
\end{tabular}


benefits derived from the wetlands, $65 \%$ and $30 \%$ of the interviewed respondents in Nabega and Shaga villages, respectively, replied that they were engaged in fishing. About $85 \%$ from Nabega and $35 \%$ from Shaga responded that they were using the wetlands for cattle grazing. In addition $25 \%$ from Nabega and $50 \%$ from Shaga replied that they were using water from the wetlands to irrigate their farm. In the focus group discussions in both villages, all came to the consensus that all of them benefitted from the wetlands either in fishing, cattle grazing or irrigating their farms. As to their future interest most of the participants in Shaga were interested to have their own share of land from the wetland for farmland. In contrast, in Nabega half of the participants of the discussion were interested to see Welala well managed for their cattle and fishing, whereas the other halve was more interested to have a share of land for farming. The information given by the respondents made it clear that Fogera Plain is under severe pressure from human impacts such as drainage for irrigation and expansion of agriculture. A practice often reported was encroachment into the wetlands following retreat cultivation of local variety of teff (Eragrostis tef) using residual moisture at the end of the rainy season. This variety of teff, locally called Bukri, flowers and produces mature seeds in 45 days. The local communities also exercised small scale wetland drainage irrigation for the cultivation of sesame, chickpea and maize [28].

According to key informants and our own field observations it was found that the inhabitants of this region lack post-harvest fish preservation methods and have no market linkage. We also found that Shesher land owners adjoining the wetlands follow the water retreat and farm until the land dries up completely. This is corroborated by a recent study [28]. It was also found that the farmlands around Welala are expanding annually at the cost of the wetlands. During the last 20 years, Shesher Wetland shrank from 1,557 hectares to 136 hectares and Welala shrank from 298 hectares to 159 hectares [28]. From our field observations it was clear that Shesher Wetland is more degraded and dries earlier in the dry season than Welala. The largest threat, however, is a huge irrigation project on Ribb River which is at presently under construction [29]. Overflow from Ribb River has been vital for maintaining an ecological connection with Lake Tana. It was observed that in the summer of 2009 there was no overflow from the river because of the construction of a levee along the bank of the river. As a result the wetlands became disconnected with Lake Tana. Direct precipitation is not sufficient for the normal functioning of these wetlands and probably they will not survive when this connection is again interrupted in the future.

\section{Conclusions}

From the study it was found that Welala and Shesher Wetlands are valuable for the local community. These wetlands are a source of fishing, water supply and grazing for livestock. The physico-chemical analysis showed that the areas are suitable for survival of aquatic organisms. Also it was found that they are important for varieties of birds' species including internationally endangered and threatened ones. However, the survival of these wetlands and associated ecological services and socio-economic importance is under a threat by unsustainable farming practices. Draining and pumping for small scale irrigation and expansion of farming are major threats. Being a common ground they are suffering from the 'tragedy of the commons'. Another potential threat is the large dam under construction on Ribb River. It is recommended to have management plans for the two wetlands and also to conduct environmental impact assessments for all future development projects around the Lake Tana.

\section{Acknowledgements}

We thank Bahir Dar University, Bahir Dar Fisheries and Aquaculture Research Center and Bureau of Culture and Tourism for financial and technical support. This study is part of an MSc project carried out at the Fisheries, Wetland and Wildlife Department of Bahir Dar University.

\section{References}

[1] Ethiopian Forestry Action Programme, "The Challenges for Development," Vol. 2, EFAP, Addis Ababa, 1989.

[2] Y. D. Abebe and K. Geheb (Eds.), "Wetlands of Ethiopia," 2003. http://data.iucn.org/dbtw-wpd/edocs/WTL-028.pdf

[3] W. J. Mitsch and J. G. Gosselink, "Wetlands," 2nd Edition, John Wiley and Sons, New York, 1993.

[4] A. Moges, "Species Composition, Distribution, Relative Abundance and Habitat Association of Avian Fauna in Fogera Plain Wetland, Ethiopia," M.Sc. Thesis, Addis Ababa University, Addis Ababa, 2008.

[5] S. Ayinalem, "Species Composition, Distribution, Relative Abundance and Habitat Association of the Bird Fauna of Bahir Dar, Zegie Peninsula and Nearby Islands," M.Sc. Thesis, Addis Ababa University, Addis Ababa, 2007.

[6] M. McCartney, T. Alemayehu, A. Shiferaw and S. B. Awulachew, "Evaluation of Current and Future Water Resources Development in the Lake Tana Basin, Ethiopia," IWMI Research Report 134, International Water Management Institute, Colombo, 2010.

[7] Improving Productivity and Market Success of Ethiopian 
Farmers, "Atlas: Fogera Wereda, Amahara," Improving Productivity and Market Success of Ethiopian Farmers, Bahir Dar, 2007.

[8] American Public Health Association, "Standard Methods for the Examination of Water and Wastewater," 20th Edition, American Public Health Association, Washington D.C., 1998.

[9] USEPA, "Sampling and Analytical Procedures for GLNPO's Open Lake Water Quality Survey of the Great Lakes; Chapter 4 - Biological Parameters; LG406 - Standard Operating Procedure for Benthic Invertebrate Field Sampling Procedure," 7th Edition, EPA 905-R-03-002, March 2003.

[10] R. W. Bouchard Jr., "Guide to Aquatic Maro-Invertebrates of the Upper Midwest," Water Resources Centre, University of Minnesota, St. Paul, 2004.

[11] J. M. Edington and A.G. Hildrew, "A Key to the Caseless Caddis Larvae of the British Isles, with Notes on Their Ecology," Freshwater Biological Association, Ambleside, 1981.

[12] T. T. Macan, "A Key to Nymphs of the British Species Ephemeroptera with Notes on Their Ecology," Freshwater Biological Association, Ambleside, 1979.

[13] D. Mueller-Dombois and H. Ellenberg, "Aims and Methods of Vegetation Ecology," John Wiley and Sons, New York, 1974.

[14] A. Kaur, "Laboratory Manual of Ecology and Environmental Studies," Paragon International Publisher, New Delhi, 2004.

[15] A. B. Tesema, "Useful Trees and Shrubs for Ethiopia: Identification, Propagation and Management for 17 Agroclimatic Zones," World Agroforestry Center, Nairobi, 2007.

[16] F. Beinhard and A. Adi, "Honeybee Flora of Ethiopia," DED Weikersheim, Margraf Verlag, 1994.

[17] M. Kent and P. Coker, "Vegetation Description and Analysis, A Practical Approach," Belhaven Press, London, 1992.

[18] M. Jones, "Study Design,” In: M. C. Bibby, M. Jones and
S. Marsden, Eds., Expedition Field Techniques, Bird Surveys, The Expedition Advisory Centre, Royal Geographical Society, London, 1998, pp. 15-34.

[19] C. Bibby, M. Jones and S. Marsden (Eds.), "Expedition Field Techniques: Bird Surveys," Expedition Advisory Centre, Royal Geographical Society, London, 1998.

[20] R. Howard and A. Moore, "A Complete Checklist of the Birds of the World" 2nd Edition, Christopher Helm Publisher, London, 1980.

[21] B. Perlo, "Collins Illustrated Checklist: Birds of East Africa," Harper Collins Publisher, London, 1995.

[22] D. V. Chapman (Ed.), "Water Quality Assessments, a Guide to the Use of Biota, Sediments and Water in Environmental Monitoring," 2nd Edition, Spon Press, Abingdon, 1996.

[23] Environmental Protection Authority of Ethiopia, "Provisional Emission Standard for Ethiopia," EPA, Addis Ababa, 2003.

[24] U.S. Environmental Protection Agency, "The Quality of our Nation's Water: A Summary of the 1988 National Water Quality Inventory," EPA Report 440/4-90-005, Washington D.C., 1990.

[25] R. Dana and M. B. Susan, "A Field Guide to Common Aquatic Plants," University of Chicago Press, Chicago, 2009.

[26] A. E. Magurran, "Ecological Diversity and Its Measurement," Chapman and Hall, London, 1988.

[27] G. J. Wallace and H. D. Mahan, "An Introduction to Ornithology," 3rd Edition, Macmillan Publisher, New York, 1975.

[28] Tonkin and Taylor International, "Environmental and Social Impact Assessment for the Ribb Dam," Supplemental Work for Ministry of Water Resources, Ministry of Water Resources, Addis Ababa, 2009.

[29] A. Getahun, E. Dejen and W. Anteneh, "Fishery Studies of Ribb River, Lake Tana Basin, Ethiopia," Vol. 2, Final Report E1573, Ethiopian Nile Irrigation and Drainage Project Coordination Office, Ministry of Water Resources, Addis Ababa, 2008. 